\title{
Place of study, field of study and labour-market region: What matters for wage differences among higher-education graduates?
}

\author{
Silvia Kopecny ${ }^{*}$ and Steffen Hillmert
}

\begin{abstract}
This paper focuses on the structure and extent of wage differences among graduates of different higher-education institutions in Germany. We ask how large these differences are and how they relate to fields of study and regional labour markets. The results from our application of cross-classified random-effects models to a cohort of the DZHW Graduate Panel show that there is a considerable amount of wage variation depending on the graduates' alma mater. However, this variation can be fully explained by structural characteristics: Selection based on individual characteristics is of only minor importance, while regional labour markets do matter. Most of all, however, the differences relate to fields of study.
\end{abstract}

Keywords: Wages, Higher-education institution, Fields of study, Regional labour markets, Multi-level analysis JEL Classification: E24, 123, 126, J31

\section{Introduction}

In contemporary societies, the relevance of education for individual life chances is well-known, especially its importance for working careers. Education determines the chances of getting a job, avoiding unemployment and attaining higher occupational positions and wage levels. In these regards, higher-education graduates tend to excel as compared to other educational levels. Therefore, it is not surprising that governments seek to increase the proportion of higher educated people in the population or that a large proportion of students aim at achieving such qualifications. However, especially in the course of the current educational expansion and the following discussion about a possible "inflation" of postsecondary degrees, questions about returns to higher education have gained attention. Empirical studies have also revealed remarkable differences in labour-market

*Correspondence: silvia.kopecny@uni-tuebingen.de

Department of Sociology, University of Tübingen, Wilhelmstr. 36, 72074 Tübingen, Germany

\section{Springer Open}

outcomes within the group of highly qualified candidates. Part of these heterogeneities can be associated with graduates' performance during their course of study (Kittelsen Røberg and Helland 2017) as well as ascriptive characteristics such as gender (Leuze and Strauß 2009). There are also structural aspects of the higher-education system that add to differences in labour-market outcomes. ${ }^{1}$ Aside from the vertical differentiation in a twotier degree structure (Noelke et al. 2012), two important horizontal dimensions of the higher-education system can be distinguished (Charles and Bradley 2002; Triventi 2013): the institution of higher education attended and the field of study.

Empirical results suggest that remarkable wage variations occur between graduates of different places of study (Britton et al. 2016; Cunha and Miller 2014; Kirkeboen et al. 2016). Higher returns have been associated

\footnotetext{
${ }_{1}^{1}$ Against the background of educational expansion, one prominent approach that emphasises the relevance of qualitative dimensions of education within the same level is Effectively Maintained Inequality, proposed by Lucas (2001). According to this approach, such dimensions are used by advantaged groups for maintaining social stratification in education.
}

(c) The Author(s) 2021. This article is licensed under a Creative Commons Attribution 40 International License, which permits use, sharing adaptation, distribution and reproduction in any medium or format, as long as you give appropriate credit to the original author(s) and the source, provide a link to the Creative Commons licence, and indicate if changes were made. The images or other third party material in this article are included in the article's Creative Commons licence, unless indicated otherwise in a credit line to the material. If material is not included in the article's Creative Commons licence and your intended use is not permitted by statutory regulation or exceeds the permitted use, you will need to obtain permission directly from the copyright holder. To view a copy of this licence, visit http://creativeco mmons.org/licenses/by/4.0/. 
with institutional characteristics, such as selectivity, prestige, and quality (Anelli 2020; Black et al. 2005; Borgen 2015; Brewer et al. 1999; Chevalier 2014; Dale and Krueger 2002; Hoekstra 2009; Monks 2000). So far, however, it has remained inconclusive whether the results actually represent a causal explanation for this wage variation through institutional characteristics or, rather, are the consequences of selection in higher-education institutions on the basis of ability (an issue which also applies for field-of-study-specific effects). Depending on the specific method of accounting for this selection, quality effects tend to decrease or even diminish, which indicates the relevance of this methodological problem.

With regard to the field of study, its major importance for labour-market returns has been emphasised in many countries (Grave and Goerlitz 2012; Iannelli et al. 2018; Reimer et al. 2008). The field-of-study-specific quantity of different kinds of human capital (van de Werfhorst and Kraaykamp 2001) and the extent of occupational specificity have been examined as explanations (Klein 2011). In addition to ability-based sorting, the different composition with respect to the fields of study offered at particular higher-education institutions might also be responsible for varying wages among institutions. The few studies that have simultaneously taken both dimensions into account have revealed wage variations along both dimensions, but the academic subject tends to be more relevant than the place of study (Belfield et al. 2018; Borgen and Mastekaasa 2018).

However, as wage formation processes do not take place within the higher-education system but on the labour market, individual wage levels may also depend on characteristics of the regional labour market (Maretzke 2013). Depending on their study location, if graduates are systematically selected into high- or low-paying labour-market regions, wage variation among graduates of different institutions can be, at least partly, a result of regional wage differences. ${ }^{2}$ Only a few studies have explicitly tackled this issue in the Scandinavian context. They have come to different conclusions, leaving room for further research (Borgen and Mastekaasa 2018; Holmlund 2009; Suhonen 2013).

In Germany, the relevance of the field of study and labour-market region for individual wages is clearly acknowledged, but the differences between specific institutions of higher education have gained less attention. A reasonable explanation is that they have been assumed to

\footnotetext{
${ }^{2}$ In analogy, the question where to work can also relate to organisational or occupational dimensions: if the attended institution promotes working in a specific high- or low-paying firm, or if the same field of study, depending on the institution of higher education, leads to high- or low-paying occupations, firms and occupation can be relevant dimensions, too. However, this would exceed the scope of this paper, where we concentrate on regional differences for now.
}

be qualitatively equivalent-a fact explicitly postulated by politics. An important distinction criterion in the highereducation system in Germany has instead been the type of institution. The two major types, universities and universities of applied sciences, differ with regard to their official educational mission (research vs. practical orientation) and structural aspects such as the fields of study offered. ${ }^{3}$ Despite the political postulate of "equivalence", graduates of the two types of institutions typically show differences in their earnings. For some fields of study, a degree from a university is advantageous, whereas for others, it is one from a university of applied sciences (Glocker and Storck 2012). Therefore, the type of highereducation institution should not necessarily be seen as an indicator of quality but rather as a structural distinction. Moreover, this institutional differentiation has declined in relevance with the introduction of bachelor's and master's degrees as a new dimension of vertical stratification. As a consequence, different types of universities in Germany have become more similar and there has been an overall convergence of the higher-education system towards the ones in Anglo-Saxon countries, which also represent the predominant cases in the corresponding state of research.

Nevertheless, there are remaining differences that might limit the transferability of international results regarding wage variation by place of study (see, for example, Allmendinger 1989; Hillmert 2001; Triventi 2013). Allocation processes and related specificities of both the higher-education systems and the labour markets differ internationally. In the case of Germany, the student population across higher-education institutions of the same type is comparatively homogeneous. This is a consequence of the fact that access is typically based on standardised entrance certificates instead of university-specific selection tests, as well as high rates of selection at earlier stages of education. Also, in the institutional landscape, there are less pronounced differences between particular institutions with regard to prestige or quality and no clearly outstanding universities, such as Oxford/Cambridge or Harvard. Finally, the German labour market is characterised by an especially high relevance of occupational specificity, which emphasises the importance of the field of study with employers.

At the same time, there are good reasons to raise the question of wage variation among graduates of different higher-education institutions in the German context. Empirical results have indicated that there are institutional differences in study quality (Grotheer and Kerst

\footnotetext{
${ }^{3}$ For detailed information on both types, see, for example, Wissenschaftsrat (2010).
} 
2011) and grading standards (Grözinger 2017). Moreover, with the government-funded Excellence Initiative/Strategy active since 2005, there has been a new differentiation between 'elite' and 'non-elite' universities, which makes differences at the institutional level at least visible-if not actively promotes them.

In this paper, we want to examine whether and to what extent there are wage differences among graduates of different higher-education institutions in Germany. Special emphases will be put on how these differences relate to the well-known wage variation by field of study and what role regional labour-market differences might play. Insights into the determinants of graduates' wages in Germany may contribute to the international state of research in a twofold way. First, they will add to the limited number of studies thus far that have considered wage differences by field of study and higher-education institution simultaneously and with a multi-level design. Second, the even scarcer but still relevant emphasis on regional labour-market differences will be extended.

In the next section, the empirical background of our study is discussed in greater detail, followed by the development of the theoretical framework, which draws on both economic and sociological approaches. Subsequently, information about the data and the applied methods, as well as our analytical strategy are provided. The consequent empirical results include descriptive evidence for each theoretical argument and multivariate estimation results. Finally, we discuss the findings and the limitations of our analysis and conclude with some remarks on the further relevance of this research.

\section{Empirical background}

The main empirical approach to investigating the relevance of the higher-education institution for graduates' earnings has been to focus on the effects of specific institutional characteristics. Research has suggested that studying at a selective, prestigious or otherwise "highquality" institution entails a higher wage on the labour market (for the United States, see Brewer et al. 1999; Dale and Krueger 2002; Hoekstra 2009; Monks 2000; Black et al. 2005; for the UK, see Chevalier 2014; for Italy, see Anelli 2020; and for Norway, see Borgen 2015). However, the aim of this study is to generally tackle the magnitude of wage variation between higher-education institutions without specifically focusing on institutional quality.

There have already been a few studies that took a similar broader perspective by examining the wage variation among higher-education institutions as whole units. These have found, for example, significant differences in Texas, Norway and the United Kingdom (Britton et al. 2016; Cunha and Miller 2014; Kirkeboen et al. 2016). Regardless of the approach, when selection is considered, there are fewer differences between higher-education institutions. This indicates that a wage premium partly results from a selection of students with a high-earning potential into specific institutions. Despite these insights, there are some caveats. In certain studies, the effects of institutions are likely to be overestimated due to the lack of selection controls (Britton et al. 2016). In others, the authors note that generalisation to a wider population might be problematic, as the applied "admission cut-off" approach includes only a very select sample (Kirkeboen et al. 2016). Cunha and Miller (2014) - as well as most of the studies examining institutional characteristicsdo not take field of study into account, although there are prominent wage differences by field of study (Iannelli et al. 2018; Reimer et al. 2008; van de Werfhorst and Kraaykamp 2001), and institutions vary in the fields of study that they offer. In the context of the US highereducation system, neglecting field of study can be justified because many students enrol in general programmes first and do not choose a major until later. In most OECD countries, however, students enrol in a specific field of study from the beginning, so it is a crucial dimension. Empirical studies examining field of study and highereducation institutions have found wage variations in both dimensions and greater relevance of field of study than the choice of institution for explaining wage variations among graduates (Belfield et al. 2018; Borgen and Mastekaasa 2018).

However, in all studies, a further explanation for wage variation among graduates of different higher-education institutions has received only minor attention: If graduates from different institutions enter the labour market systematically in high- or low-paying regions, their wage variations can be partially a consequence of regional wage differences. While Belfield et al. (2018) discussed the point theoretically, they drew no conclusions for the empirical analysis. Other authors included the location where the student grew up as well as an indicator of whether the region of work is similar to the location of the higher-education institution in their analyses (Borgen and Mastekaasa 2018). As the results were stable, they concluded that wage variation was not due to regional wage differences. However, the indicators in use are only proxies for labour-market regions rather than the regional labour market where graduates actually work. Studies using the latter indicate that regional wage differences or the location of the higher-education institution in combination with the work region are relevant for wage variation (Holmlund 2009; Suhonen 2013).

Therefore, we would like to improve our common understanding of the relevance of regional wage differences for the wage variations related to higher-education institution and fields of study. 


\section{Theoretical considerations}

From an economic perspective, wages are the result of an exchange process in the labour market between workers, who supply their manpower, and employers, who demand it. According to economic market models, these processes of supply and demand determine the levels of payment. In contrast, in sociological theory, it is not only market processes that play a crucial role in the level of payment but also institutional and social power relations (Hinz and Abraham 2008). From both perspectives, however, the importance of education is acknowledged, although mainly in the form of education levels. Regarding the level of formal education, higher-education graduates represent a homogeneous group, but there are several possibilities of internal differentiation. Individual features, such as performance criteria, as well as ascriptive characteristics, such as gender or social origin, vary among higher-education graduates. Moreover, the decision to study entails two associated decisions that also depend on the higher-education system: the choice of what to study and where to do so. For Germany, we can assume that the decision for a field of study comes first and is followed by the choice of location/institution. Vocationalism is traditionally a central principle of working life, and there is a strong link between fields of study and the actual occupation rewarded in the German labour market. For some fields of study, eligible highereducation institutions are limited to universities. For example, more traditional fields of study, such as medicine or law, are only offered at universities and not at universities of applied sciences. From a rational choice point of view, prospective students choose the field of study and the higher-education institutions that are expected to yield the highest utility, given cost and benefits calculations (Becker et al. 2010; Esser 1999). Regarding highereducation institutions in Germany, it is only known that there are different returns by type of higher-education institution, but not whether some are more beneficial than others among the same type.

Given a field of study, how can the choice of a highereducation institution be associated with wage variation? There are four primary arguments proposed in the literature (Gerber and Cheung 2008). The first follows the human capital approach (Becker 1994) in assuming that higher-education institutions vary in their quality and therefore impart different amounts of skills and knowledge-human capital-to their students. Consequently, graduates' productivity in the labour market differs, and so do their wages. Second, the higher-education institution where someone graduated can be used by an employer as a signal of the graduate's productivity (Spence 1973). A relevant precondition here is that employers know differences in institutional reputation.
Third, graduates can be provided with social capital differently, depending on their alma mater. Therefore, it might not be (assumed) differences in productivity but, rather, social relationships that may be responsible for wage differences, given that higher-education-based networks can be used to get high-paying jobs. These causal mechanisms are not only difficult to separate empirically, but the role of the higher-education institution as an underlying cause is also questioned in more recent studies supporting the fourth argument of selection processes. As already mentioned, holders of a university entrance certificate with high earnings potential may self-select or be selected into specific higher-education institutions. Consequently, the wages of students who graduate from such institutions are higher on average, but the relation is not a causal one.

While this selection problem is, in different methodological ways, addressed in nearly every study of institutional effects, two other explanations have gained less attention. Wage variations among higher-education institutions can also result from the field-of-study composition of their graduates. There are well-known wage differences by field of study, and among institutions of higher education, both the offered fields of study and their number of graduates vary. Therefore, field of study should be included in the analysis of wage variations in association with higher-education institutions. Moreover, wage levels in the German labour market are not homogeneous; instead, they vary regionally (Fuchs et al. 2014; Ragnitz 2012). If graduates of specific institutions enter the labour market in particularly high- or low-paying regions, the mean wage gained by graduates of the higher-education institutions is associated with the regional wage level. The most evident case to think of is that high proportions of graduates enter the labour market in the region where they graduate (or the region of residence before studying if they were mobile when taking up studies). This could already be shown for the mobility behaviour of German graduates (Haußen and Übelmesser 2015; Krabel and Flöther 2014). Universities and universities of applied sciences differ regarding their regional locations. While universities are mostly found in larger cities and traditional university towns, universities of applied sciences are located not only in larger cities but also in smaller cities in more rural regions. Due to the connection between higher-education institutions and graduates' labour market regions with differing wage levels, the two issues should be examined simultaneously in order to get a better understanding of their relevance to wage differences among higher-education graduates.

The main focus of this study is, therefore, not to prove possible causal mechanisms based on characteristics of higher-education institutions such as quality, but 
to investigate whether there is wage variation among academic institutions as whole units, how it relates to variation by field of study and whether parts of this heterogeneity are mediated by regional labour-market wage differences.

\section{Data, methods and analytical strategy}

We drew on data from the Graduate Panel of the German Centre for Higher Education Research and Science Studies (DZHW), which conducts a regular survey of higher-education graduates in Germany (Brandt et al. 2018). Graduates of the cohort of 2009 (winter term 2008/2009 and summer term 2009) were surveyed 1.5 and 5 years after graduation and interviewed about their higher-education experiences, transition to the labour market and labour-market success. The dataset includes information on 10,494 graduates from 179 higher-education institutions (including universities, specific colleges such as teacher training or art colleges, which also belong to the group of universities in the binary federal classification, and universities of applied sciences) that cover 58 fields of study. ${ }^{4}$ Although the time of labour-market entry of this cohort fell directly into the aftermath of the economic crisis of $2008 / 2009$, graduates' transition processes do not seem to have been more difficult compared to previous cohorts (Rehn et al. 2011). We restricted the sample to graduates who entered the labour market with their first degree to have a clear assignment to the higher-education institution (approximately $76 \%$ of all graduates). Because there is at labour-market entry a greater relevance of education for labour-market outcomes as compared to other well-known influences, such as work experience, we focussed on the job the respondents referred to as their first one after graduation in the questionnaire. Moreover, we included only graduates age 35 or younger (only $3.4 \%$ of all graduates exceed this age limit).

To select the first significant job, we also did not consider workers who had marginal employment (monthly wage below $€ 450$ or weekly working time below $15 \mathrm{~h}$ ) in order to get an even more homogeneous sample focussed on the core of the labour market. Also excluded from our analysis were those who were self-employed and graduates who were in further training while working. The major reason for this decision is that wage formation processes in these types of employment differ significantly in the extent to which they follow market principles. This means that we concentrated on employees

\footnotetext{
${ }^{4}$ However, not every field of study was observed at each higher-education institution due to either non-availability or sampling design (see Baillet et al. 2017 for more details), and the cluster sizes vary. Therefore, we have a rather unbalanced data structure (Table 4 in Appendix).
}

and civil servants. It is noteworthy that the latter group is very small in our sample due to the early point in the graduates' careers targeted in the first wave of the survey. In particular, prospective teachers and law graduates were still in their special transition processes and were therefore not represented in the sample. With these parameters, approximately $60 \%$ of the respondents who had provided information regarding their first job were covered. $^{5}$

To match the individual information with regional labour-market indicators at the level of the workplace's administrative region, only employees who work in Germany could be included. This could theoretically lead to sample bias if a large number of particularly highpotential graduates from specific higher-education institutions take up employment abroad. However, only $2.3 \%$ of all graduates take a job outside of Germany, and there is no indication of bias. The share of graduates taking up employment abroad varies between 0 and $29 \%$ across institutions, but its correlation with the mean wages across higher-education institutions is minimal (Pearson's $r=0.1, p<0.001$ ). Our final analysis sample consisted of 2175 observations with complete information. They were distributed across 147 higher-education institutions, 53 fields of study and all 38 administrative regions in Germany [Regierungsbezirke]. Hence, approximately $1 / 3$ of all higher-education institutions in Germany are covered in our sample, and the distribution of the various types of institutions sufficiently matches the population. In our sample, the breakdown was $47 \%$ universities and 53\% universities of applied sciences, compared to $43 \%$ universities and $57 \%$ universities of applied sciences in the population.

It should be mentioned that universities in our sample comprised mostly traditional institutions, while specific types of universities (theological colleges, arts colleges) are underrepresented. However, this selection can be expected to strengthen the validity of our results for traditional universities and universities of applied sciences, which are the most important types of higher-education institutions in Germany. Moreover, our sample can address nearly all fields of study, and it covers all regions of Germany.

As the dependent variable, we used the logarithm of the gross hourly wage, which was calculated from the

\footnotetext{
${ }^{5}$ Additional analyses of an identical sample of higher-education institutions that used data from the whole working population indicate greater variations attributable to the institution once the field of study and labour-market region are considered. Hence, the employment patterns also seem to vary by institution. They might be an interesting further explanation for wage differences, but they are not the focus of this study. For the reported results using the restricted sample, this means that the estimates are rather conservative.
} 
gross monthly wage, including bonus payments, divided by contractual working hours. ${ }^{6}$ The independent dimensions of interest were primarily in line with the classifications of the Federal Statistical Office. For the purposes of data protection, higher-education institution is a categorical variable in the form of an anonymised identifier provided by the Data Research Centre of the DZHW. Field of study is categorised in 58 units following the second level of the field-of-study classification of 2008/2009 (Statistisches Bundesamt n.d.). We chose two different ways to represent regional labour markets. On the one hand, the location information for the first job in the survey was used as a categorical variable on the level of administrative regions $(N=38)$ corresponding to NUTS-2 units for international classification (see, for example, Europäische Kommission 2015). ${ }^{7}$ On the other hand, for each administrative region of workplaces, we added regional earnings data from the online database INKAR, managed by the Federal Institute for Research on Building, Urban Affairs and Spatial Development (BBSR; BBSR Bonn 2019). We drew from external data because we suspect endogeneity problems if the wage levels by institution and by region are derived from the same sample. To have a control independent of academically educated workers, we used data on the earnings of full-time workers who hold a vocational degree ${ }^{8}$ and whose jobs are subject to social insurance contributions. Earnings information by educational level is available in the form of the median gross monthly wage as of the year 2014, and we used this information in units of $€ 100$.

Finally, we used a set of individual-level characteristics to account for selection, applying a selection-onobservables approach. We included gender, age, grade of the higher-education entrance certificate (1.0 being the best and 4.0 the worst grade in Germany, but reversely coded in estimations for easier interpretation as a positive indicator of performance) and social origin (at least one parent obtained a higher-education degree) because these characteristics influence the choice of a specific

\footnotetext{
${ }^{6}$ There is minimal heterogeneity regarding the time graduates enter the labour market. Therefore, we did not adjust the wage for inflation.

${ }^{7}$ Current territorial structures in Germany consist of fewer administrative regions because they were dissolved in some federal states. However, the aggregation of three-digit postal codes in the survey data follows the international NUTS-2 classification, where they are still included for reasons of comparability.

${ }^{8}$ Analyses including the wage levels of academically trained workers instead of the wage levels of vocationally trained workers show similar results. The endogeneity problem might already be addressed by the fact that the external wage indicator includes the full-time employed and academically trained across all ages and career phases, while our sample consists only of labour-market entrants not older than 35 in full- and part-time employment.
}

institution as well as earned wages. Moreover, type of degree and type of higher-education institution were controlled to address differing wage levels (Rehn et al. 2011). The cohort at hand studied before the institutional implementation of the new degree structure was completed. Therefore, a first degree at this point covers bachelor's and traditional degrees (diploma and, partly, Magister) along with the still existing state examinations. As the proportions of degrees varied across types of institutions, we used a combined indicator. See Table 1 for an overview of all of the study's variables.

To simultaneously model the association between wage variation and higher-education institutions as well as fields of study, we applied a crossed random-effects model (Rabe-Hesketh and Skrondal 2012, p. 433), also referred to as the cross-classified model (Hox et al. 2010, p. 171), to a continuous variable. In contrast to a hierarchical random-effects model, where units of the individual level are nested in one cluster of each hierarchical level, crossed models account for data structures where units belong to cross-classified and therefore non-hierarchical higher-level clusters. In our case, the assumption was that graduates' wages vary according to the specific institution attended and field of study, given that a field of study can be offered at different institutions.

The model is specified as

$$
y_{i j k}=\beta_{1}+\beta X_{i j k}+\beta W_{j}+\zeta_{1 j}+\zeta_{2 k}+\epsilon_{i j k}
$$

where $y_{i j k}$ is the outcome variable log(wage) for graduate $i$ of higher-education institution $j$ in the field of study $k ; \beta_{1}$ is the intercept; $X_{i j k}$ represent the individual-level control variables and $W_{j}$ is the type of degree and highereducation institution. The random intercepts for the institution and the field of study are indicated by $\zeta_{1 j}$ and $\zeta_{2 k}$, respectively. Our main interest lies in their estimated standard deviations that indicate the variability of wages among institutions within a field of study, and vice versa. Finally, $\epsilon_{i j k}$ is the residual error term. Depending on the operationalisation of regional labour markets, this model is extended by either the external regional wage level as an individual-level fixed effect ${ }^{9}$ or the categorical identifier of administrative regions as a third crossed random factor (Eq. (2)). ${ }^{10}$

\footnotetext{
9 The model assumption that individual-level variables need to be independent of not only the individual error term but also the higher-level error term (i.e., the random effects) should be considered. We tested this random-effects assumption by additionally estimating a model that also includes the clustermean of regional wage and compared the models using a likelihood-ratio test, following Antonakis et al. (2019). There is no indication of level-2 endogeneity regarding the indicator of regional wage because the likelihood-ratio test is not significant at any conventional significance level (Table 5 in Appendix).

10 In crossed random-effects models, the variances of the random intercepts for the dimensions are assumed to be additive. This means that the variation across higher-education institutions is the same for all fields of
} 
Table 1 Description of model variables

\begin{tabular}{|c|c|c|c|c|c|c|}
\hline & $N$ & Mean & Median & SD & Min & Max \\
\hline Gross hourly wage in $€$ & 2175 & 16.14 & 16.09 & 5.73 & 2.76 & 74.20 \\
\hline NUTS-2 monthly earnings in $€ 100$ & 2175 & 28.62 & 29.75 & 4.11 & 19.54 & 33.27 \\
\hline Grade of entrance certificate & 2175 & 2.26 & 2.30 & 0.62 & 1.00 & 3.90 \\
\hline Gender (female) & 2175 & 0.56 & 1.00 & 0.50 & 0.00 & 1.00 \\
\hline Age (years) & 2175 & 28.62 & 28.00 & 2.25 & 23.00 & 35.00 \\
\hline Parents with higher education & 2175 & 0.54 & 1.00 & 0.50 & 0.00 & 1.00 \\
\hline \multicolumn{7}{|l|}{ Type of degree and institution } \\
\hline Diploma_University of applied sciences & 2175 & 0.22 & 0.00 & 0.41 & 0.00 & 1.00 \\
\hline Diploma/Magister_University & 2175 & 0.36 & 0.00 & 0.48 & 0.00 & 1.00 \\
\hline Bachelor-University of applied sciences & 2175 & 0.19 & 0.00 & 0.39 & 0.00 & 1.00 \\
\hline Bachelor-University & 2175 & 0.10 & 0.00 & 0.30 & 0.00 & 1.00 \\
\hline State Examination_University & 2175 & 0.13 & 0.00 & 0.34 & 0.00 & 1.00 \\
\hline \multicolumn{7}{|l|}{ Dummies of } \\
\hline Higher-education institutions (147 units) & 2175 & & & & & \\
\hline Fields of study (53 units) & 2175 & & & & & \\
\hline Administrative regions (NUTS-2) (38 units) & 2175 & & & & & \\
\hline
\end{tabular}

Data source: DZHW Graduate Panel 2009; BBSR Bonn 2019, authors' calculations

SD Standard deviation

$$
y_{i j k l}=\beta_{1}+\beta X_{i j k l}+\beta W_{j}+\zeta_{1 j}+\zeta_{2 k}+\zeta_{3 l}+\epsilon_{i j k l}
$$

Both models show the relevance of regional wage differences at the level of administrative regions to wage variation across institutions and fields of study in the change of the respective variance components. Thereby, the strength of the first specification lies in the use of external wage data, while the advantage of the model given in Eq. (2) is the possibility of estimating the amount of variance in graduates' wages attributable to the level of regional labour markets.

We begin by estimating a two-level null model without covariates, where just the intercept and the variance component of higher-education institutions are estimated in order to get the raw wage variation that can be associated with that level. Then, the set of individuallevel characteristics is added to consider selection, and the type of degree and higher-education institution is

\footnotetext{
Footnote 10 (continued)

study (and regional labour markets), and vice versa. To relax this assumption, an interaction term of the random factors can be included as an additional level. However, most combinations of higher-education institutions and fields of study are represented by only one type of degree in the data, especially when the labour-market region is controlled for. As type of degree is included in the estimated models, the variance proportion associated with the interaction term is already covered, and an additional control would lead to an overspecification. Therefore, only additive crossed random-effects models are used.
}

included to address corresponding wage differences. In the next model specification, the higher level is extended by introducing the field of study as a crossed random factor. Finally, regional labour markets are considered by adding either the external wage level or the third crossed random factor, as described above. To estimate the models, the command mixed in Stata (Version 16) software was used. ${ }^{11}$

\section{Empirical results}

Before the estimation results of the random-effects models are presented, some descriptive analyses may illustrate the theoretical arguments. In our sample, graduates earn an average hourly wage of $€ 16.14$ in their first job after graduation (Table 2). The average wage level across higher-education institutions (mean of the mean wages earned by graduates of the higher-education institutions) is $€ 15.85$, and the average wage of graduates' wage aggregation by field of study is $€ 14.53$. The coefficient of variation, also called the relative standard deviation, confirms that the dispersion of the respective wage is greatest at the individual level with 0.36 . At the level of higher-education institutions and fields of study, there are relatively similar results, with values of 0.22 and 0.19 , respectively. In Fig. 1, the mean wages across higher-education institutions and the respective confidence intervals (at the

\footnotetext{
${ }^{11}$ See, for example, Marchenko (2006) for an implementation of various random-effects models in Stata.
} 
Table 2 Description of wage and earnings variables (in $€$ )

\begin{tabular}{lrrrrrrr}
\hline & \multicolumn{1}{c}{$\boldsymbol{N}$} & Mean & Median & \multicolumn{1}{c}{ SD } & Min & Max & CV \\
\hline Gross hourly wage & 2175 & 16.14 & 16.09 & 5.73 & 2.76 & 74.20 & 0.36 \\
Mean wage across higher-education institutions & 147 & 15.85 & 15.75 & 3.40 & 6.13 & 28.00 & 0.22 \\
Mean wage across fields of study & 53 & 14.53 & 13.80 & 2.77 & 8.91 & 22.39 & 0.19 \\
Mean monthly earnings across NUTS-2 & 38 & 2810.63 & 2901.75 & 390.81 & 1954.00 & 3327.00 & 0.14 \\
\hline
\end{tabular}

Data source: DZHW Graduate Panel 2009; BBSR Bonn 2019, authors' calculations

$S D$ standard deviation, $C V$ coefficient of variation

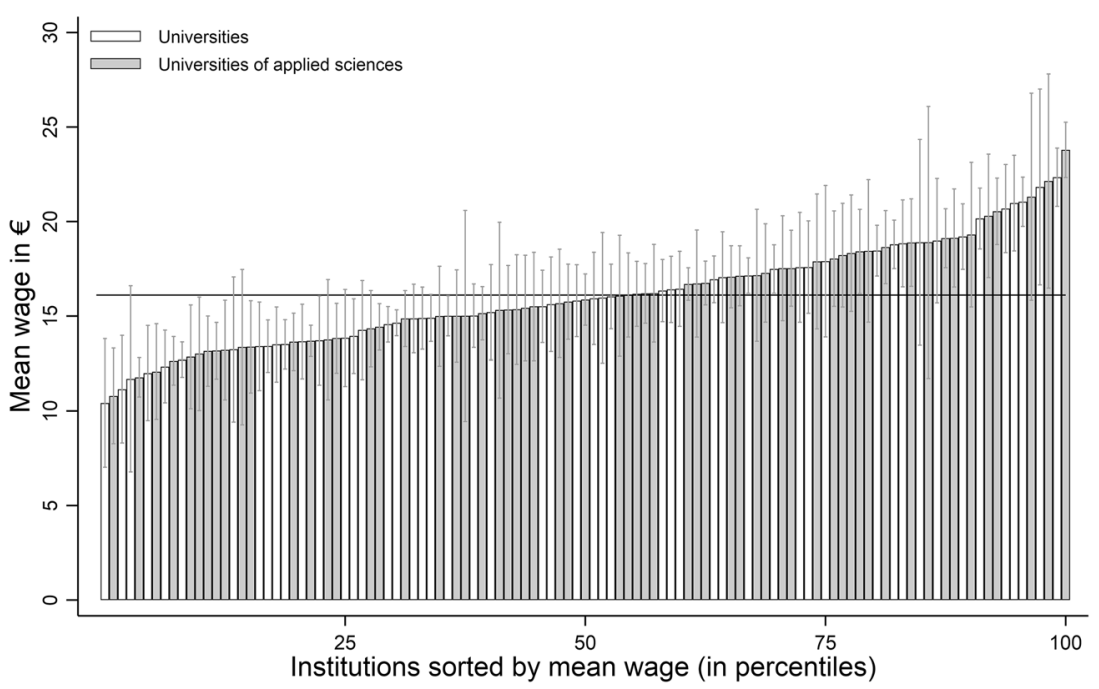

Fig. 1 Mean wages across higher-education institutions. Only units with at least five observations are displayed; horizontal line: (unweighted) mean of institution-specific wages, 90\% confidence interval. Data source: DZHW Graduate Panel 2009, authors' calculations

90\% level) are presented. The anonymised higher-education institutions are sorted in ascending order of the mean wage of their graduates. The figure shows considerable variation, ranging from approximately $€ 10$ for the university whose graduates earn the average lowest wages to $€ 23$ for a university of applied sciences whose graduates have, on average, earned the highest wages. For some values, the confidence intervals are rather large due to small cluster sizes. However, as these cases are unsystematically spread across the distribution, this does not change the overall pattern. Against the background of the two types of higher-education institutions in Germany, it is noteworthy that the differing wage levels do not simply represent institutional differences between universities and universities of applied sciences; in fact, the distributions of the two types are rather similar (see also Fig. 6 in Appendix).

There is also considerable wage variation depending on the field of study, as can be seen in the distribution of fields of study sorted by the mean wage of graduates (Fig. 2). On average, English and American studies pay the least, and human medicine pays the most. ${ }^{12}$ These results are consistent with the state of research that graduates of fields of study with high occupational specificity earn higher wages in the labour market than graduates of fields of study with low occupational specificity. Again, the dispersion reaches from approximately $€ 10$ at the bottom up to about $€ 23$ at the top, but the differences are more striking because there are fewer distinct fields of study. In summary, there are notable wage variations along both dimensions. Additional analyses showed that the standard deviation of the individual wage attributable to differences between higher-education institutions is much smaller than the standard deviation attributable to differences within them. This also holds true for wage differences by field of study, indicating once again a similar

\footnotetext{
${ }^{12}$ See Table 6 in Appendix for an overview of all fields of study and their corresponding mean wages.
} 


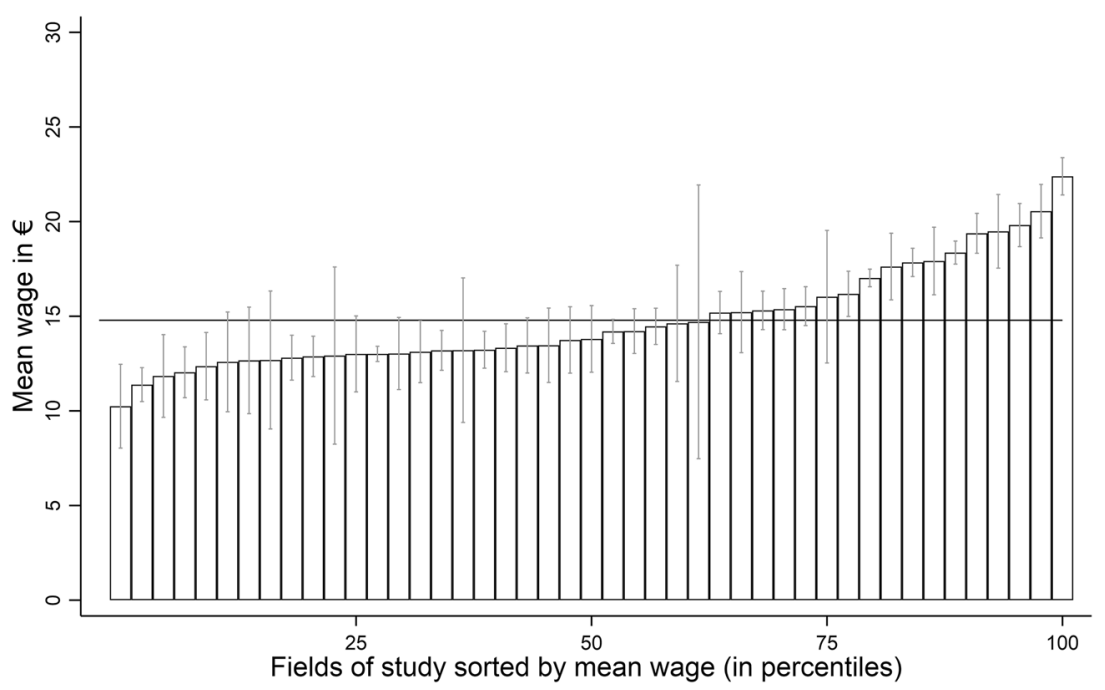

Fig. 2 Mean wages across fields of study. Only units with at least five observations are displayed; horizontal line: (unweighted) mean of field-of-study-specific wages, 90\% confidence intervals. Data source: DZHW Graduate Panel 2009, authors' calculations

relevance of higher-education institutions and fields of study in wage differences among graduates.

However, higher-education institutions differ in the study programmes they offer and in the size of their graduation cohorts per field of study. Consequently, fields of study differ in the higher-education institutions where they are available. Therefore, the question arises of how the two dimensions are related and whether the composition of fields of study accounts for the wage variation among higher-education institutions. Figure 3 shows the dispersion in the form of coefficients of variation for field-of-study-specific mean wages related to the different higher-education institutions. Here, the extent of differences across fields of study can be seen when looking at specific higher-education institutions. The institutions are sorted according to their specific value of this variation. Only higher-education institutions with at least two fields of study are presented, and again, only the mean wages of fields of study with at least five observations are calculated. This explains the considerable reduction in the number of higher-education institutions in this figure. For the presented institutions, three important aspects can be noted. First, and not surprisingly, the strong differences across fields of study are present even within higher-education institutions. Second, the wage dispersion across fields of study is not the same for each institution. This might be explained by the number and kinds of fields of study offered at each institution (or represented in our data). Third, there is again no clear pattern of differences between universities and universities of applied sciences.
In Fig. 4, the two analytical dimensions are switched so that the wage dispersion within fields of study and across higher-education institutions is shown, again represented by coefficients of variation. And again, the variation across higher-education institutions is not at all homogeneous across fields of study. While it is almost zero for the field of study with the smallest dispersion, it lies above $20 \%$ for the field of study with the highest dispersion. In general, the results indicate that even if the field of study is held constant, there are still wage differences among graduates of different higher-education institutions. Comparing both figures, differences by field of study within institutions seems to be more relevant than differences by higher-education institutions within fields of study. This is in line with our expectations because subject-oriented vocationalism is a well-known characteristic of the German labour market.

So far, two horizontal dimensions of the higher-education system have been the focus. However, wage-generation processes take place in the labour market, which is itself heterogeneous. Figure 5, left-hand panel, and Table 2 show the varying earnings of academically trained workers across administrative regions, with values from approximately $€ 1954$ to $€ 3327$ per month. This result emphasises regional wage differences not only between East and West but also on a less aggregated level. Therefore, it is not only important where students study and which subject, but also where they work as graduates. In this respect, mobility behaviour in the labour market has already gained considerable attention (see Ganesch et al. 2019 or Kratz and Brüderl 2013 for all education levels; Faggian et al. 2007 for international graduates; Haußen 


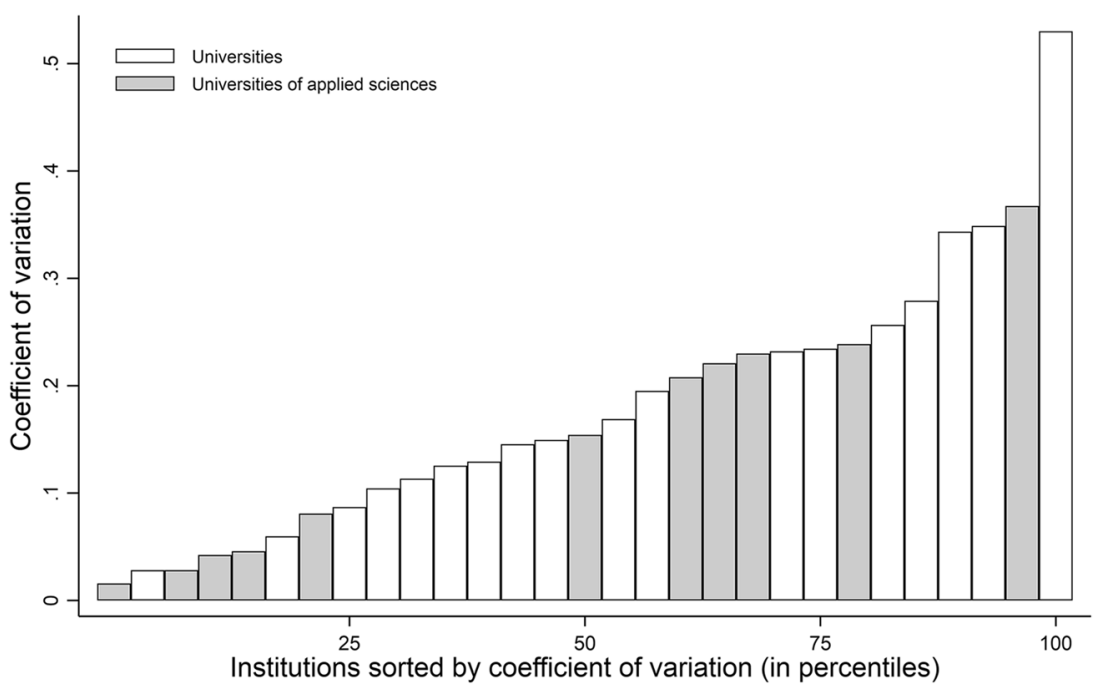

Fig. 3 Coefficient of variation of mean wages across fields of study, by higher-education institutions. Only fields of study with at least five observations are used for calculating the mean, and only institutions with more than two fields of study are displayed. Data source: DZHW Graduate Panel 2009, authors' calculations

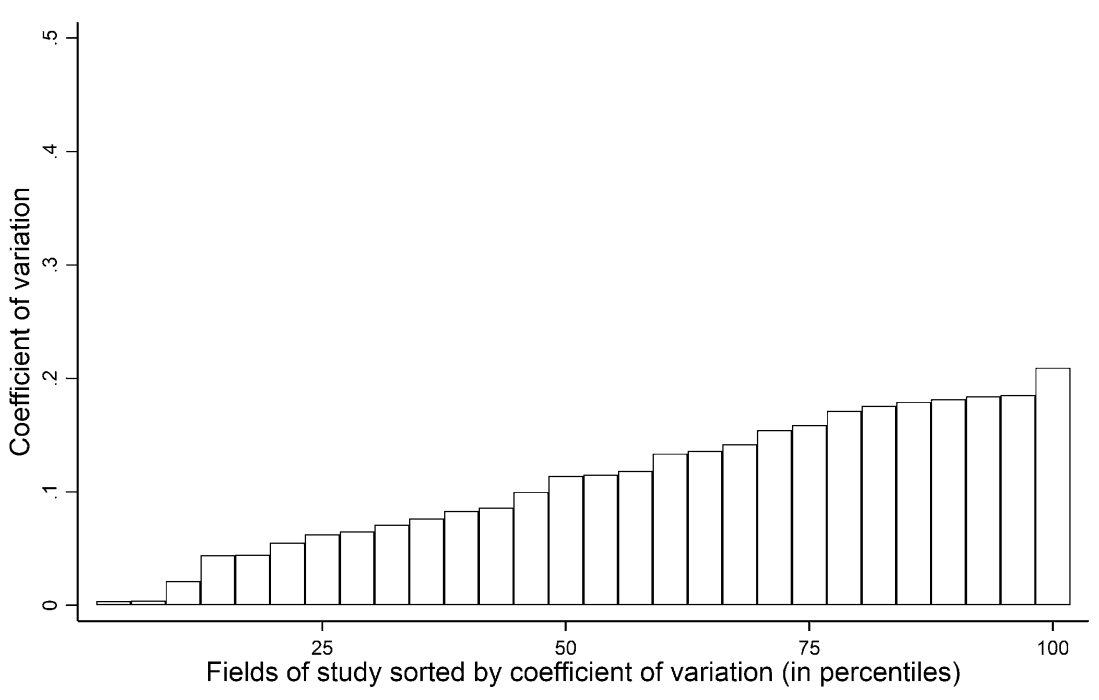

Fig. 4 Coefficient of variation of mean wages across higher-education institutions, by field of study. Only institutions with at least five observations are used for calculating the mean, and only fields of study at more than two institutions are displayed. Data source: DZHW Graduate Panel 2009, authors' calculations

and Übelmesser 2015 and Krabel and Flöther 2014 for German graduates; and Falk and Kratz 2009 for Bavarian graduates). For the question at hand, it is crucial whether graduates' mobility behaviour and the wage levels at their destination workplaces are connected to the respective higher-education institution. Such an expectation is confirmed by a relatively high correlation between the higher-education institution and the administrative region of the workplace (Cramer's $V=0.60$ ). Consistent with previous research, the majority of graduates in the sample (69\%) enter the labour market in the federal state where their alma mater is located. In large part, they are graduates who never left the federal state where they achieved their higher-education entrance certificate and, to a lesser extent, graduates who moved to begin their studies and stayed. However, higher-education institutions differ in their graduates' mobility behaviour. Figure 5 , right-hand panel, shows the varying proportion of 

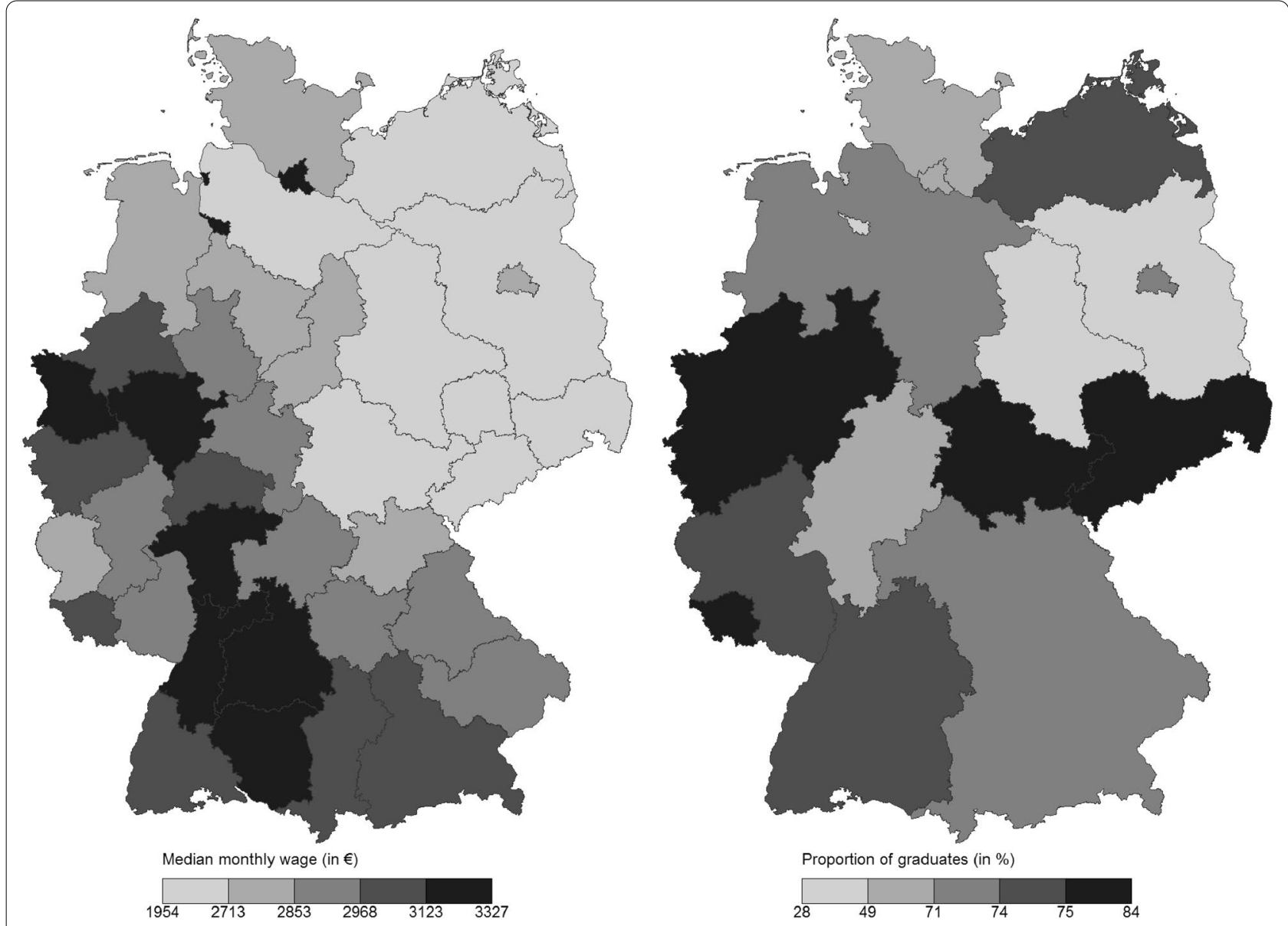

Fig. 5 Regional differences. Left panel, median monthly earnings across administrative regions (in $€$ ) and right panel, proportion of graduates staying in the federal state of graduation (in \%); categories are based on quintile classes. Data source: BBSR Bonn 2019; DZHW Graduate Panel 2009; authors' calculations

graduates entering the labour market in the federal state where they graduated, ranging from 28 to $84 \%$. These differences in mobility behaviour can be explained partly by regional labour-market conditions. For example, a higher mean wage in the federal state is slightly associated with a higher share of graduates staying for their first job (Pearson's $r=0.07, p<0.01) .{ }^{13}$ Hence, graduates' respective mobility behaviour varies across higher-education institutions and is also related with regional labour-market conditions. Therefore, it may also be related to the mean wage of graduates from specific higher-education institutions. This possibility is not covered by controlling for the place of study or mobility, but only by considering the workplace in any form. Of course, these analyses of

\footnotetext{
${ }^{13}$ Further results for the relationship of regional labour market conditions and mobility behaviour can be found in Buch et al. (2017) or Ganesch et al. (2019).
}

mobility patterns are not sufficient to make causal claims. However, they support the argument of the relevance of regional labour markets in wage variations among graduates of different higher-education institutions. ${ }^{14}$

The descriptive results indicate that there is considerable wage variation by higher-education institution as well as variation by field of study. However, when studying both dimensions and looking at wage variations by higher-education institutions within a field of study, the variation becomes significantly smaller. Thus, wage differences between higher-education institutions can be attributed in great part, but not completely, to the fact that they offer different fields of study (or offer them in different compositions). Simultaneously, regional wage

\footnotetext{
14 There is also related research, particularly on links between higher-education institutions and regional development (see, for example, Peer and Penker 2016).
} 
Table 3 Estimation results of random-effects models of log hourly wage

\begin{tabular}{|c|c|c|c|c|c|c|}
\hline & Mo & M1 & M2 & M3 & M4a & M4b \\
\hline $\begin{array}{l}\text { Grade of entrance certificate } \\
\text { (reverse-coded) }\end{array}$ & & $0.052^{* * *}(0.013)$ & $0.047^{* * *}(0.013)$ & $0.035^{* *}(0.013)$ & $0.037^{* *}(0.012)$ & $0.037^{* *}(0.012)$ \\
\hline Gender (female) & & $-0.146^{* * *}(0.016)$ & $-0.137^{* * *}(0.016)$ & $-0.076^{* * *}(0.017)$ & $-0.074^{* * *}(0.016)$ & $-0.077^{* * *}(0.016)$ \\
\hline Age (years) & & $0.021^{* * *}(0.004)$ & $0.016^{* * *}(0.004)$ & $0.011^{* * *}(0.003)$ & $0.011^{* *}(0.003)$ & $0.011^{* * *}(0.003)$ \\
\hline Parents have higher education & & $0.019(0.016)$ & $0.010(0.015)$ & $0.004(0.015)$ & $0.013(0.014)$ & $0.010(0.014)$ \\
\hline \multicolumn{7}{|l|}{$\begin{array}{l}\text { Degree at type of institution } \\
\text { (ref. diploma-UAS) }\end{array}$} \\
\hline Diploma/Magister_Univ. & & & $-0.028(0.031)$ & $0.031(0.027)$ & $0.029(0.023)$ & $0.031(0.023)$ \\
\hline Bachelor-UAS & & & $-0.086^{* *}(0.027)$ & $-0.096^{* * *}(0.024)$ & $-0.106^{* * *}(0.023)$ & $-0.095^{* * *}(0.023)$ \\
\hline Bachelor-Univ. & & & $-0.241^{* * *}(0.037)$ & $-0.162^{* * *}(0.033)$ & $-0.164^{* * *}(0.030)$ & $-0.152^{* * *}(0.030)$ \\
\hline State examination—UAS & & & $-0.040(0.039)$ & $-0.080^{\sim}(0.045)$ & $-0.078^{\sim}(0.041)$ & $-0.081^{\sim}(0.041)$ \\
\hline NUTS-2 earnings (in €100) & & & & & $0.016^{* * *}(0.002)$ & \\
\hline Constant & $2.711^{* * *}(0.015)$ & $2.027^{* * *}(0.116)$ & $2.262^{* * *}(0.119)$ & $2.287^{* * *}(0.116)$ & $1.844^{* * *}(0.127)$ & $2.276^{* * *}(0.115)$ \\
\hline \multicolumn{7}{|l|}{ Random effects part } \\
\hline SD (HEI) & $0.138^{* * *}(0.014)$ & $0.122^{* * *}(0.013)$ & $0.117^{* * *}(0.012)$ & $0.064^{* * *}(0.012)$ & $0.024^{* * *}(0.021)$ & $0.020^{* * *}(0.023)$ \\
\hline SD (Individual) & $0.352^{* * *}(0.006)$ & $0.342^{* * *}(0.005)$ & $0.338^{* * *}(0.005)$ & $0.319^{* * *}(0.005)$ & $0.317^{* * *}(0.005)$ & $0.316^{* * *}(0.005)$ \\
\hline $\mathrm{SD}$ (FoS) & & & & $0.156^{* * *}(0.019)$ & $0.156^{* * *}(0.019)$ & $0.157^{* * *}(0.019)$ \\
\hline SD (AdReg) & & & & & & $0.068^{* * *}(0.012)$ \\
\hline Log-likelihood & -889.831 & -820.196 & -788.158 & -675.637 & -645.644 & -652.993 \\
\hline ICC HEI & 0.134 & 0.112 & 0.108 & 0.031 & 0.004 & 0.003 \\
\hline ICC FoS & & & & 0.188 & 0.194 & 0.191 \\
\hline ICC AdReg & & & & & & 0.036 \\
\hline Nindividuals & 2175 & 2175 & 2175 & 2175 & 2175 & 2175 \\
\hline NHEI & 147 & 147 & 147 & 147 & 147 & 147 \\
\hline NFOS & 53 & 53 & 53 & 53 & 53 & 53 \\
\hline NAdReg & 38 & 38 & 38 & 38 & 38 & 38 \\
\hline
\end{tabular}

Standard errors in parentheses, standard deviations of random effects are reported

$\sim p<0.10,{ }^{*} p<0.05,{ }^{* *} p<0.01,{ }^{* * *} p<0.001$

Data source: DZHW Graduate Panel 2009; BBSR Bonn 2019, authors' calculations

UAS university of applied sciences, Univ. university, HEl higher-education institution, FoS field of study, AdReg administrative region

differences seem to be related to wage variation by institution as the mobility behaviour of graduates varies across institutions and is known to be dependent on regional labour-market conditions. So far, we have neglected this selection problem, and the dimensions were not considered simultaneously. Now we draw on crossed random-effects models that include all these aspects. The estimation results are shown in Table 3.

In the null model (M0), the estimated standard deviation of the institutions' intercepts from the overall mean is 0.138 wage log points, or $14 \%$. Given the overall mean in the sample of approximately $€ 16$, this standard deviation equals $€ 1.20$. Given an approximately normally distributed random variable, approximately $68 \%$ of the values lie within one standard deviation around the mean. Thus, it is estimated that for a majority of highereducation institutions, the mean hourly wage of their graduates lies between $€ 14.80$ and $€ 17.20$. The intra-class correlation (ICC) indicates that the considerable proportion of $13 \%$ of the wage variance can be attributed to differences among higher-education institutions.

When including individual-level characteristics to consider selection in higher-education institutions (M1) as well as the combined indicator of type of degree and higher-education institution (M2), the standard deviations at both the aggregate and individual levels decreases slightly. Consequently, the ICC decreases slightly to $11 \%$. This is a surprisingly small reduction, given that selection in higher education institutions is considered particularly important in international research. However, it supports the expectation that selection is not as important for wage differences among higher-education institutions in Germany. ${ }^{15}$ Despite the fact that our models

\footnotetext{
${ }^{15}$ However, the composition of graduates at higher-education institutions, fields of study and the administrative region of the workplace vary strongly in our sample (Table 7 in Appendix).
} 
have not been specified for measuring the effects of the following variables, the estimated coefficients are mostly in line with known findings. The coefficients for grade of higher-education entrance certificate, gender and age point in the typical direction and are statistically significant at conventional levels, while parental education is not. Regarding the types of degrees offered at different types of institutions, the results show no significant differences between universities and universities of applied sciences for graduates with traditional degrees and even significantly lower wages for state examination degrees. ${ }^{16}$ For bachelor graduates, the results are consistent with the current state of the research, showing significantly lower wages in general and even more so for graduates of universities. However, it needs to be acknowledged that a selection-on-observables approach was taken, and although the most evident individual-level determinants were included in the model, it is possible that not all relevant aspects were considered. We might therefore underestimate the relevance of selection, so the results should not be interpreted in a causal way.

In the next model (M3), the aggregate level is extended by the field of study as a factor cross-classified with higher-education institution. The standard deviation for the level of higher-education institutions shows a significant decrease to $0.064 \log$ points, or $6 \%$. This is a clearly smaller value than the $0.156 \log$ points, or $16 \%$, that are attributable to fields of study. The ICC states that only $3 \%$ of wage variance can be associated with higher-education institution and $19 \%$ with field of study. Hence, there are two important things to note. First, wage differences among graduates of specific higher-education institutions are promoted by differences in the available fields of study, but they are not completely accounted for by these. This is consistent with the descriptive results above. Second, a comparison of the dimensions indicates that, in Germany, what someone studies is much more important for wage variation than where they study. Given the strong links between fields of study and occupations in the labour market, this was expected.

In the final set of models, the dimension of the labourmarket region was added as the final piece of the puzzle. It was operationalised in the form of the regional level of monthly earnings as fixed effect (M4a) and as a further crossed random factor using the categorical identifier (M4b). With any $€ 100$ increase of the regional earnings, the individual-level wage increases by $1.6 \%$ on

\footnotetext{
${ }^{16}$ With regard to this result, the specificity of the sample at hand should be considered. Unlike other studies that have covered the whole working population, our sample targets an early point in the career, when typically high-earning graduates of fields of study at universities, such as teaching or law, are still in the phase of transition to the labour market.
}

average, given the control variables and random factors. The standard deviation of higher-education institutions' intercepts decreases by approximately $0.040 \log$ points when labour-market regions are considered as a fixed effect. This results in an ICC of $0 \%$. Thus, while the relevance of the field of study is relatively unaffected by the regional labour market, the wage level of the location where graduates enter the labour market for their first job seems to contribute to wage differences among graduates of higher-education institutions, but not to wage differences among graduates of different fields of study. In the model with the labour-market region as a third crossed random factor (M4b), the wage intercepts of the administrative regions are based on the wage information collected from the graduates in the sample. Due to the proximity to the dependent variable and the fact that not only the regional wage level, but also all other regional aspects are represented by the administrative region dummies, a strong decrease of wage variation at the level of higher-education institutions could be expected when compared to the model with two additive crossed random factors and the external wage indicator (M4a). However, in both models, the reduction pattern looks rather similar. Looking at the proportion of variance on the respective level, as indicated by the intra-class correlations, there is $0 \%$ of wage variation attributable to the level of higher-education institutions, 19\% corresponding to field-of-study differences and $4 \%$ associated with the administrative region of the workplace, controlling for individual-level characteristics and the combined indicator of type of degree and higher-education institution.

To sum up, wage variations among graduates depending on their alma mater are considerable. The reduction of variance between the models with different indicators shows that this variation can be associated to a small extent with selection based on individual-level characteristics, to a greater extent with regional labour-market differences and, most of all, with differences between fields of study. ${ }^{17}$

\section{Discussion and conclusion}

Against the backdrop of wage heterogeneity between not only graduates of different educational levels but also within the group of higher-education graduates, the focus of this study was on the labour-market relevance of the specific higher-education institution in Germany. We described wage variations among graduates of different alma maters and examined to what extent this wage heterogeneity can be associated with differences in

\footnotetext{
${ }^{17}$ We also varied the order of inclusion of the sets of different variables, and the results were robust.
} 
represented fields of study and in the regional conditions under which graduates enter the labour market for their first job, while also considering selection processes. It has been argued that, other than possible mechanisms based on institutional characteristics, the field-of-study composition can be associated with wage variation between higher-education institutions. Moreover, the mobility behaviour of German graduates is characterised by great proportions entering the labour market in the region where their alma mater is located. As there are wage differences not only between East and West Germany but also among less aggregated spatial units, such as administrative regions, wage variations from higher-education institutions can be associated with regional wage levels. For the empirical analyses, cross-classified randomeffects models were applied to data on the 2009 cohort from the DZHW Graduate Panel. Results indicated that there is considerable wage variation attributable to higher-education institutions, which is especially related to the fields of study offered and the labour-market region in which graduates take up their first job; only to a lesser extent is the variation due to selection based on individual-level characteristics. Beyond the dimensions considered in these analyses, the residual level of wage variation associated with higher-education institutions is miniscule.

However, there are also some limitations regarding data, operationalisation and the methodological approach that should be mentioned. First, the data are quite unbalanced, with many cells consisting of only a few observations. On the one hand, this situation results from the fact that not every field of study is offered at every higher-education institution and the size of a field of study varies considerably. On the other hand, a reason can be found in the sampling design of the Graduate Panel and varying response rates. Especially when considering higher-education institutions, fields of study and labour-market regions simultaneously, the number of observations in the respective cells drops significantly. In fact, crossed random-effects models can deal with unbalanced data, but their power decreases with many small cells. Therefore, a more balanced and larger dataset containing the relevant information in comparable detail would be advantageous. Unfortunately, such data are, to our knowledge, not yet available in Germany. Second, only the higher-education institution of graduation has been considered, but not whether graduates studied at other institutions in prior years. Because the aim of the study was not to prove causal mechanisms, such as human capital arguments, this is of minor importance. Otherwise, the time spent at each institution would have been an obvious aspect to consider. Third, there are several issues regarding the operationalisation of the regional labour market. It is questionable whether the studied administrative regions are the best representation of regional labour markets, because the latter do not necessarily follow administrative borders. The problem of defining the right spatial scope is also well known as the "modifiable areal unit problem" in spatial analyses (Hillmert et al. 2017; Madelin et al. 2009). Especially if wage differences are of interest, administrative regions can be too broad, and more narrow regional classifications such as planning regions, labour-market regions or even counties can be more suitable (see, for example, Ganesch et al. 2019). Hence, a comparison of different spatial operationalisations is an interesting task for further research. An additional aspect that needs to be considered when adding external spatial data is the temporal dimension. Spatial classification codes and indicators tend to change over time, and they should match with the points of time represented in the data. In our case, the graduates entered the labour market between 2008 and 2010. Yet the regional indicator we used was available only from 2014 on, so there was a small delay. This might be problematic given that our graduates' labour market entries fall into the aftermath of the economic crises in 2008/2009. However, the consistency of a comparable indicator that is not differentiated by educational level but available for a longer time period is very high (Pearson's $r=0.99, p<0.001$, values for the years 2009 and 2014). The same applies for a comparison between this indicator and the one in use in 2014 (Pearson's $r=0.86, p<0.001)$. This indicates that we have used a sufficient proxy for the labour-market situation despite the time lag and the economic crisis. ${ }^{18}$ Fourth, following our argument regarding potential endogeneity problems, an external indicator might be useful not only for the regional wage level but also for field-of-study-specific wages. Given an adequate database, this might be another option for further research. Finally, we used a selection-on-observables approach to address selection into higher-education institutions. Although the most prominent aspects have been included, relevant aspects might still be missing. In this case, the variations in higher-education institutions, fields of study and labourmarket regions can be overestimated, and the relevance of selection underestimated. Therefore, we would like to emphasise that no causal conclusion should be drawn from these results, which primarily intend to provide a detailed description.

Nevertheless, relevant insights into some processes of wage heterogeneity in Germany can already be gained.

\footnotetext{
${ }^{18}$ Additional analyses including this undifferentiated indicator of 2009 confirmed that the substantial results are robust.
} 
It could be shown that there are considerable wage variations among graduates of different higher-education institutions that are related to fields of study and regional labour markets. And although the residual wage variation attributable to higher-education institutions is minimal when considering individual-level characteristics, as well as fields of study and regional labour markets, it does not necessarily mean that higher-education institutions are unimportant for wage differences among graduates. It only indicates that their relevance works through different, more indirect channels. Which fields of study are offered at particular institutions of higher education is the choice of their leadership. There are also indications that the relevance of the alma mater varies across fields of study. An interesting further research issue is, therefore, to examine which fields of study the specific highereducation institution is particularly relevant for and why. Moreover, the question of where higher-education institutions are located seems to be important for the average wage level of graduates, as many graduates enter the labour market at the location of their academic training. This is also relevant for infrastructure policies regarding the planning of where new institutions of higher education should be founded. It also emphasises the necessity of dealing with regional wage differences in Germany in greater detail, although differences between East and West are the dominant dimension in this variation. ${ }^{19}$ Further research could therefore deepen our understanding of the relevance of regional labour markets by examining the specific mechanisms behind wage differences and the spatial scope in which they take place. Finally, the results refer to specific points in time with regard to both the careers of individuals and historical time. While the relevance of the alma mater might be expected to decline with increasing experience over the course of a career, it may increase for future cohorts against the backdrop of growing differentiation and competition in the highereducation system.

\section{Appendix}

See Tables 4, 5, 6, 7, 8 and Fig. 6.

Table 4 Description of the sample

\begin{tabular}{|c|c|c|c|c|c|}
\hline & Mean & Median & SD & Min & Max \\
\hline Individuals $(\mathrm{N}=2175)$ & - & - & - & - & - \\
\hline \multicolumn{6}{|l|}{ Units: higher-education institutions ( $N=147)$} \\
\hline Number of graduates per unit & 14.80 & 11 & 14.82 & 1 & 92 \\
\hline Number of fields of study per unit & 3.69 & 3 & 2.87 & 1 & 16 \\
\hline Number of administrative regions where graduates work per unit & 4.98 & 5 & 3.40 & 1 & 23 \\
\hline \multicolumn{6}{|l|}{ Units: fields of study $(\mathrm{N}=53)$} \\
\hline Number of graduates per unit & 41.04 & 27 & 62.55 & 1 & 415 \\
\hline Number of higher-education institutions per unit & 10.25 & 7 & 10.22 & 1 & 55 \\
\hline Number of administrative regions where graduates work per unit & 12.75 & 12 & 8.10 & 1 & 33 \\
\hline \multicolumn{6}{|l|}{ Units: administrative regions $(\mathrm{N}=38)$} \\
\hline Number of graduates per unit & 57.24 & 40.5 & 51.12 & 2 & 212 \\
\hline Number of higher-education institutions per unit & 19.26 & 16.5 & 12.09 & 2 & 51 \\
\hline Number of fields of study per unit & 17.79 & 17.5 & 8.08 & 2 & 37 \\
\hline \multicolumn{6}{|l|}{ Units: higher-education institutions $\times$ fields of study $(N=543)$} \\
\hline Number of graduates per unit & 4.01 & 2 & 5.24 & 1 & 44 \\
\hline \multicolumn{6}{|l|}{$\begin{array}{l}\text { Units: higher-education institutions } \times \text { fields of study } \times \\
\text { administrative regions }(N=1143)\end{array}$} \\
\hline Number of graduates per unit & 1.90 & 1 & 2.46 & 1 & 31 \\
\hline
\end{tabular}

Data source: DZHW Graduate Panel 2009, authors' calculations

SD standard deviation 
Table 5 Test of random-effects assumption (model with and without cluster mean of earnings indicator)

\begin{tabular}{|c|c|c|}
\hline & M4a & M4a_CM \\
\hline Grade of entrance certificate (reverse-coded) & $0.037^{* *}(0.012)$ & $0.037^{* *}(0.012)$ \\
\hline Gender (female) & $-0.074^{* * *}(0.016)$ & $-0.074^{* * *}(0.016)$ \\
\hline Age (years) & $0.011^{* *}(0.003)$ & $0.011^{* *}(0.003)$ \\
\hline Parents have higher education & $0.013(0.014)$ & $0.013(0.014)$ \\
\hline \multicolumn{3}{|l|}{ Degree at type of institution (ref. diploma_UAS) } \\
\hline Diploma/Magister_Univ. & $0.029(0.023)$ & $0.029(0.023)$ \\
\hline Bachelor-UAS & $-0.106^{* * *}(0.023)$ & $-0.106^{* * *}(0.023)$ \\
\hline Bachelor-Univ. & $-0.164^{* * *}(0.030)$ & $-0.165^{* * *}(0.030)$ \\
\hline State Examination-UAS & $-0.078^{\sim}(0.041)$ & $-0.078^{\sim}(0.041)$ \\
\hline NUTS-2 earnings (in €100) & $0.016^{* * *}(0.002)$ & $0.014^{* * *}(0.003)$ \\
\hline Cluster mean of NUTS-2 earnings (in $€ 100$ ) & & $0.002(0.004)$ \\
\hline Constant & $1.844^{* * *}(0.127)$ & $1.821^{* * *}(0.132)$ \\
\hline \multicolumn{3}{|l|}{ Random-effects part } \\
\hline SD (HEI) & $0.024^{* * *}(0.021)$ & $0.023^{* * *}(0.021)$ \\
\hline SD (Individual) & $0.156^{* * *}(0.019)$ & $0.156^{* * *}(0.019)$ \\
\hline SD (FoS) & $0.317^{* * *}(0.005)$ & $0.317^{* * *}(0.005)$ \\
\hline Log-Likelihood & -645.644 & -645.457 \\
\hline LR-test (chi-square) & & 0.374 \\
\hline LR-test (p) & & 0.541 \\
\hline ICC HEI & 0.004 & 0.004 \\
\hline ICC FoS & 0.194 & 0.194 \\
\hline Nindividuals & 2175 & 2175 \\
\hline NHEI & 147 & 147 \\
\hline NFOS & 53 & 53 \\
\hline
\end{tabular}

Standard errors in parentheses; standard deviations of random effects are reported $\sim p<0.10,{ }^{*} p<0.05,{ }^{* *} p<0.01,{ }^{* * *} p<0.001$

Data source: DZHW Graduate Panel 2009, BBSR Bonn 2019, authors' calculations

UAS university of applied sciences, Univ. university, HEl higher-education institution, FoS field of study 
Table 6 Description of wages (in €), by fields of study, sorted by mean

\begin{tabular}{|c|c|c|c|c|c|c|}
\hline Field of study & $N$ & Mean & Median & SD & Min & Max \\
\hline English and American studies & 12 & 10.25 & 9.00 & 4.27 & 4.93 & 19.16 \\
\hline Architecture, interior design & 40 & 11.39 & 11.49 & 3.36 & 5.17 & 19.16 \\
\hline Design & 21 & 11.84 & 10.58 & 5.81 & 5.17 & 26.18 \\
\hline German studies & 39 & 12.04 & 11.97 & 4.97 & 2.87 & 21.43 \\
\hline Administrative science & 15 & 12.36 & 12.55 & 3.91 & 4.60 & 19.60 \\
\hline Romance studies & 9 & 12.59 & 12.07 & 4.25 & 6.90 & 20.11 \\
\hline Comparative literature studies and linguistics & 8 & 12.67 & 12.58 & 4.20 & 6.33 & 20.35 \\
\hline Prot. theology/religious doctrine & 7 & 12.69 & 11.77 & 4.96 & 7.24 & 19.16 \\
\hline Landscape management, environmental design & 34 & 12.81 & 12.51 & 4.09 & 4.38 & 24.08 \\
\hline Special pedagogy & 29 & 12.88 & 12.41 & 3.37 & 5.25 & 23.10 \\
\hline Spatial planning & 6 & 12.92 & 10.78 & 5.69 & 7.57 & 22.75 \\
\hline Forestry, wood industry & 11 & 13.01 & 12.26 & 3.67 & 7.66 & 18.68 \\
\hline Social services & 121 & 13.01 & 13.18 & 2.67 & 6.90 & 23.75 \\
\hline History & 16 & 13.03 & 12.95 & 4.34 & 8.05 & 20.40 \\
\hline Geography & 27 & 13.12 & 13.26 & 4.98 & 3.45 & 21.46 \\
\hline Linguistic and cultural sciences & 36 & 13.20 & 13.07 & 3.74 & 7.36 & 19.16 \\
\hline Music, musicology & 5 & 13.21 & 13.54 & 4.00 & 8.67 & 18.76 \\
\hline Dental medicine & 41 & 13.23 & 12.64 & 3.71 & 6.96 & 21.35 \\
\hline Social sciences & 37 & 13.33 & 14.32 & 4.56 & 4.60 & 21.07 \\
\hline Business and social studies, generally & 28 & 13.46 & 13.28 & 4.53 & 6.51 & 21.66 \\
\hline Library science, documentation & 17 & 13.46 & 13.41 & 4.64 & 6.90 & 26.05 \\
\hline Political sciences & 20 & 13.75 & 14.17 & 4.53 & 5.75 & 20.75 \\
\hline Agricultural sciences & 27 & 13.80 & 14.56 & 5.36 & 3.54 & 28.54 \\
\hline Educational sciences & 91 & 14.20 & 13.57 & 3.65 & 6.44 & 25.69 \\
\hline Veterinary medicine & 33 & 14.21 & 13.22 & 4.01 & 8.03 & 22.43 \\
\hline Psychology & 62 & 14.47 & 14.84 & 4.52 & 5.81 & 26.82 \\
\hline Geosciences (without geography) & 12 & 14.62 & 13.79 & 5.93 & 6.57 & 27.53 \\
\hline Sports, sports science & 7 & 14.70 & 10.25 & 9.85 & 7.18 & 33.33 \\
\hline Chemistry & 46 & 15.19 & 16.95 & 4.51 & 6.67 & 24.03 \\
\hline Surveying & 16 & 15.22 & 16.38 & 4.89 & 4.54 & 22.99 \\
\hline Law & 47 & 15.31 & 14.52 & 4.15 & 5.89 & 24.14 \\
\hline Health sciences & 43 & 15.37 & 15.52 & 4.23 & 6.72 & 24.84 \\
\hline Biology & 41 & 15.53 & 16.22 & 3.89 & 6.59 & 22.99 \\
\hline Food sciences and home economics & 11 & 16.03 & 16.09 & 6.41 & 7.25 & 26.72 \\
\hline Physics, astronomy & 49 & 16.18 & 17.44 & 4.98 & 5.75 & 29.69 \\
\hline Economic sciences & 415 & 17.02 & 17.31 & 5.75 & 3.33 & 60.54 \\
\hline Civil engineering & 45 & 17.62 & 16.09 & 7.03 & 8.62 & 54.50 \\
\hline Computer science & 123 & 17.84 & 17.24 & 5.01 & 7.36 & 40.23 \\
\hline General engineering & 18 & 17.92 & 18.49 & 4.36 & 6.90 & 25.24 \\
\hline Mechanical engineering, process engineering & 144 & 18.36 & 18.07 & 4.41 & 7.66 & 31.85 \\
\hline Industrial engineering & 77 & 19.38 & 19.16 & 5.55 & 6.39 & 37.72 \\
\hline Mathematics & 34 & 19.49 & 21.28 & 6.70 & 4.89 & 31.89 \\
\hline Electrical engineering & 66 & 19.82 & 18.79 & 5.54 & 7.36 & 43.44 \\
\hline Traffic engineering, nautical science & 40 & 20.55 & 20.11 & 5.30 & 8.05 & 31.69 \\
\hline Human medicine & 129 & 22.39 & 21.84 & 6.76 & 2.76 & 74.20 \\
\hline Total & 2155 & 2155 & 2155 & 2155 & 2155 & 2155 \\
\hline
\end{tabular}

Only fields of study with at least five observations are reported; Data: DZHW Graduate Panel 2009, authors' calculations SD standard deviation 
Table 7 Graduates' characteristics across higher-education institutions, fields of study and administrative regions

\begin{tabular}{|c|c|c|c|c|c|c|}
\hline & $N$ & Mean & Median & SD & Min & Max \\
\hline \multicolumn{7}{|l|}{ Individuals } \\
\hline Grade of entrance certificate & 2175 & 2.26 & 2.30 & 0.62 & 1.00 & 3.90 \\
\hline Proportion of females & 2175 & 0.56 & 1.00 & 0.50 & 0.00 & 1.00 \\
\hline Age (years) & 2175 & 28.62 & 28.00 & 2.25 & 23.00 & 35.00 \\
\hline Parents with higher education & 2175 & 0.54 & 1.00 & 0.50 & 0.00 & 1.00 \\
\hline \multicolumn{7}{|l|}{ Higher-education institutions } \\
\hline Mean grade of entrance certificate & 147 & 2.32 & 2.32 & 0.33 & 1.20 & 3.15 \\
\hline Mean proportion of females & 147 & 0.53 & 0.56 & 0.30 & 0.00 & 1.00 \\
\hline Mean age (years) & 147 & 28.62 & 28.60 & 1.42 & 24.50 & 35.00 \\
\hline Mean proportion of parents with higher education & 147 & 0.50 & 0.50 & 0.27 & 0.00 & 1.00 \\
\hline \multicolumn{7}{|l|}{ Fields of study } \\
\hline Mean grade of entrance certificate & 53 & 2.22 & 2.29 & 0.31 & 1.25 & 2.90 \\
\hline Mean proportion of females & 53 & 0.61 & 0.71 & 0.29 & 0.00 & 1.00 \\
\hline Mean age (years) & 53 & 28.37 & 28.45 & 0.96 & 25.00 & 30.25 \\
\hline Mean proportion of parents with higher education & 53 & 0.57 & 0.52 & 0.18 & 0.00 & 1.00 \\
\hline \multicolumn{7}{|l|}{ Administrative regions } \\
\hline Mean grade of entrance certificate & 38 & 2.28 & 2.27 & 0.18 & 1.92 & 2.67 \\
\hline Mean proportion of females & 38 & 0.57 & 0.57 & 0.11 & 0.35 & 1.00 \\
\hline Mean age (years) & 38 & 28.57 & 28.70 & 0.55 & 26.50 & 29.43 \\
\hline Mean proportion of parents with higher education & 38 & 0.50 & 0.50 & 0.17 & 0.00 & 0.84 \\
\hline
\end{tabular}

Data source: DZHW Graduate Panel 2009, authors' calculations

SD standard deviation 
Table 8 Estimation results of random-effects models of log hourly wage for workers in West Germany only

\begin{tabular}{|c|c|c|c|c|c|c|}
\hline & Mo & M1 & M2 & M3 & M4a & M4b \\
\hline $\begin{array}{l}\text { Grade of entrance certificate } \\
\text { (reverse-coded) }\end{array}$ & & $0.052^{* * *}(0.015)$ & $0.049^{* *}(0.015)$ & $0.042^{* *}(0.014)$ & $0.040^{* *}(0.014)$ & $0.042^{* *}(0.014)$ \\
\hline Gender (female) & & $-0.129^{* * *}(0.018)$ & $-0.119^{* * *}(0.018)$ & $-0.057^{* *}(0.019)$ & $-0.057^{* *}(0.019)$ & $-0.057^{* *}(0.019)$ \\
\hline Age (years) & & $0.023^{* * *}(0.004)$ & $0.017^{* * *}(0.004)$ & $0.011^{* *}(0.004)$ & $0.011^{* *}(0.004)$ & $0.011^{* *}(0.004)$ \\
\hline Parents have higher education & & $0.030^{\sim}(0.018)$ & $0.021(0.018)$ & $0.019(0.016)$ & $0.018(0.016)$ & $0.019(0.016)$ \\
\hline \multicolumn{7}{|l|}{$\begin{array}{l}\text { Degree at type of institution } \\
\text { (ref. diploma-UAS) }\end{array}$} \\
\hline Diploma/Magister_Univ. & & & $-0.052(0.033)$ & $-0.004(0.026)$ & $-0.003(0.026)$ & $-0.004(0.026)$ \\
\hline Bachelor-UAS & & & $-0.098^{* * *}(0.030)$ & $-0.129^{* * *}(0.026)$ & $-0.129^{* * *}(0.026)$ & $-0.129^{* * *}(0.026)$ \\
\hline Bachelor-Univ. & & & $-0.270^{* * *}(0.040)$ & $-0.213^{* * *}(0.033)$ & $-0.211^{* * *}(0.033)$ & $-0.213^{* * *}(0.033)$ \\
\hline State examination-UAS & & & $-0.055(0.042)$ & $-0.125^{* *}(0.047)$ & $-0.123^{* *}(0.047)$ & $-0.125^{* *}(0.047)$ \\
\hline NUTS-2 earnings (in €100) & & & & & $0.008^{\sim}(0.005)$ & \\
\hline Constant & $2.756^{* * * *}(0.016)$ & $2.006^{* * *}(0.132)$ & $2.274^{* * *}(0.136)$ & $2.335^{* * *}(0.130)$ & $2.086^{* * *}(0.194)$ & $2.335^{* * *}(0.130)$ \\
\hline \multicolumn{7}{|l|}{ Random-effects part } \\
\hline SD (HEI) & $0.138^{* * *}(0.016)$ & $0.119^{* * *}(0.015)$ & $0.111^{* * *}(0.014)$ & $0.025^{* * *}(0.025)$ & $0.023^{* *}(0.028)$ & $0.025^{* * *}(0.025)$ \\
\hline SD (Individual) & $0.346^{* * *}(0.006)$ & $0.337^{* * *}(0.006)$ & $0.332^{* * *}(0.006)$ & $0.312^{* * *}(0.006)$ & $0.312^{* * *}(0.006)$ & $0.312^{* * *}(0.006)$ \\
\hline $\mathrm{SD}$ (FoS) & & & & $0.164^{* * *}(0.020)$ & $0.164^{* * *}(0.020)$ & $0.164^{* * *}(0.020)$ \\
\hline SD (AdReg) & & & & & & $0.000^{* * *}(0.000)$ \\
\hline Log-Likelihood & -629.361 & -580.346 & -551.332 & -454.278 & -452.782 & -454.278 \\
\hline ICC HEI & 0.137 & 0.112 & 0.100 & 0.005 & 0.004 & 0.005 \\
\hline ICC FOS & & & & 0.215 & 0.216 & 0.215 \\
\hline ICC AdReg & & & & & & 0.000 \\
\hline Nindividuals & 1593 & 1593 & 1593 & 1593 & 1593 & 1593 \\
\hline NHEI & 142 & 142 & 142 & 142 & 142 & 142 \\
\hline NFOS & 52 & 52 & 52 & 52 & 52 & 52 \\
\hline NAdReg & 30 & 30 & 30 & 30 & 30 & 30 \\
\hline
\end{tabular}

Standard errors in parentheses; standard deviations of random effects are reported

$\sim p<0.10,{ }^{*} p<0.05,{ }^{* *} p<0.01,{ }^{* * *} p<0.001$

Data source: DZHW Graduate Panel 2009; BBSR Bonn 2019, authors' calculations

UAS university of applied sciences, Univ. university, HE/ higher-education institutions, FoS field of study, AdReg administrative region

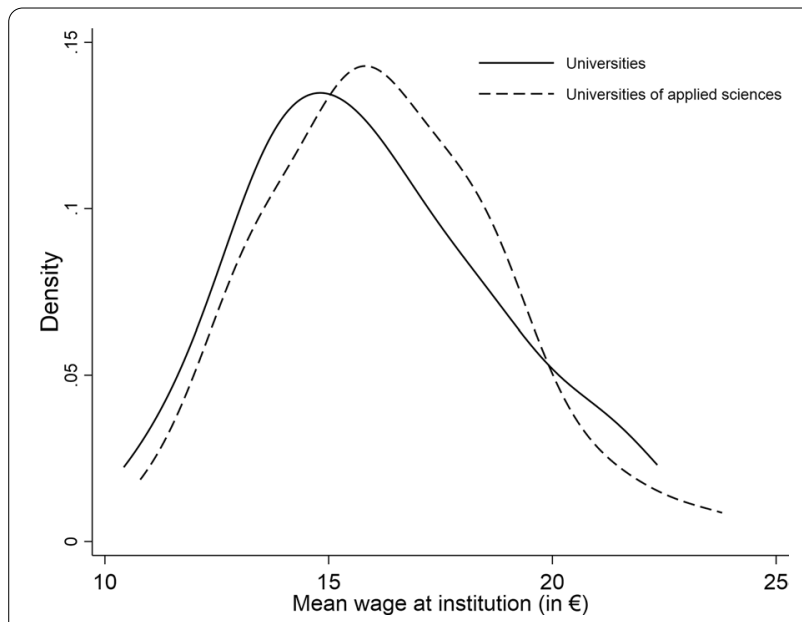

Fig. 6 Distribution of mean wage across institutions, by type of institution. Gaussian kernel density distribution. Data source: DZHW Graduate Panel 2009, authors' calculations

\section{Acknowledgements}

The authors would like to thank the service team of the FDZ-DZHW for their valuable help. We would also like to acknowledge that part of the research was conducted while the first author was a researcher at the Bavarian State Institute for Higher Education Research and Planning in Munich.

\section{Authors' contributions}

All authors read and approved the final manuscript.

\section{Funding}

Not applicable.

\section{Availability of data and materials}

The individual-level dataset analysed during the current study is available at the Research Data Centre of the German Centre for Higher Education Research and Science Studies (FDZ-DZHW) repository, https://doi.org/10. 21249/DZHW:gra2009:1.0.1. The additional earnings data are available in the online database INKAR of the Federal Institute for Research on Building, Urban Affairs and Spatial Development (BBSR), (BBSR Bonn 2019). 


\section{Declarations}

Ethics approval and consent to participate

Not applicable.

\section{Consent for publication}

Not applicable.

\section{Competing interests}

The authors declare that they have no competing interests.

Received: 16 September 2020 Accepted: 22 June 2021

Published online: 13 July 2021

\section{References}

Allmendinger, J.: Educational systems and labor market outcomes. Eur. Sociol. Rev. 5(3), 231-250 (1989)

Anelli, M.: The returns to elite university education: a quasi-experimental analysis. J. Eur. Econ. Assoc. 18(6), 2824-2868 (2020). https://doi.org/10. 1093/jeea/jvz070

Antonakis, J., Bastardoz, N., Rönkkö, M.: On ignoring the random effects assumption in multilevel models: review, critique, and recommendations. Organ. Res. Methods 24(2), 443-483 (2019). https://doi.org/10.1177/ 1094428119877457

Baillet, F., Franken, A., Weber, A.: DZHW-Absolventenpanel 2009. Daten-und Methodenbericht zu den Erhebungen der Absolvent(inn)enkohorte 2009 (1. und 2. Befragungswelle) (2017)

Becker, G.S.: Human Capital: A Theoretical and Empirical Analysis with Special Reference to Education. University of Chicago Press, Chicago (1994)

Becker, R., Haunberger, S., Schubert, F.: Studienfachwahl als Spezialfall der Ausbildungsentscheidung und Berufswahl. ZAF 42(4), 292-310 (2010)

Belfield, C., Britton, J., Buscha, F., Dearden, L., Dickson, M., van der Erve, L., Sibieta, L., Vignoles, A., Walker, I., Zhu, Y.: The relative labour market returns to different degrees: research report: June 2018. Institute for Fiscal Studies. https://assets.publishing.service.gov.uk/government/uploads/system/ uploads/attachment_data/file/714517/The_relative_labour_market-retur ns to different degrees.pdf (2018). Accessed 9 May 2021

Black, D., Daniel, K., Smith, J.: College quality and wages in the United States. Ger. Econ. Rev. 6(3), 415-443 (2005)

BBSR Bonn: Federal institute for research on building, urban affairs and spatial development. https://www.inkar.de (2019). Accessed 14 Sept 2020

Borgen, N.T.: College quality and the positive selection hypothesis: the 'second filter' on family background in high-paid jobs. Res. Soc. Stratif. Mobil. 39 32-47 (2015)

Borgen, N.T., Mastekaasa, A.: Horizontal stratification of higher education: the relative importance of field of study, institution, and department for candidates' wages. Soc. Forces 97(2), 531-558 (2018)

Brandt, G., Briedis, K., Fabian, G., Klüver, S., Rehn, T., Trommer, M.: DZHWAbsolventenpanel 2009. Datenerhebung: 2010-2015. Version: 1.0.1. In: Datenpaketzugangsweg: Remote-Desktop-SUF. Hannover: FDZ-DZHW. Datenkuratierung: Baillet, F., Franken, A., Weber, A. (2018). https://doi.org/ 10.21249/DZHW:gra2009:1.0.1

Brewer, D.J., Eide, E.R., Ehrenberg, R.G.: Does it pay to attend an elite private college? Cross-cohort evidence on the effects of college type on earnings. J. Hum. Resour. 34(1), 104-123 (1999)

Britton, J., Dearden, L., Shephard, N., Vignoles, A.: How English domiciled graduate earnings vary with gender, institution attended, subject and socio-economic background. IFS working papers (2016).

Buch, T., Hamann, S, Niebuhr, A, Rossen, A. How to woo the smart ones? Evaluating the determinants that particularly attract highly qualified people to cities. J. Urban Aff. 39(6), 764-782 (2017)

Charles, M., Bradley, K.: Equal but separate? A cross-national study of sex segregation in higher education. Am. Sociol. Rev. 67(4), 573-599 (2002). https://doi.org/10.2307/3088946

Chevalier, A.: Does higher education quality matter in the UK? Res. Labor Econ. 40(1), 257-292 (2014)
Cunha, J.M., Miller, T.: Measuring value-added in higher education: possibilities and limitations in the use of administrative data. Econ. Educ. Rev. 42 64-77 (2014). https://doi.org/10.1016/j.econedurev.2014.06.001

Dale, S.B., Krueger, A.B.: Estimating the payoff to attending a more selective college: an application of selection on observables and unobservables. Q. J. Econ. 117(4), 1491-1527 (2002)

Esser, H.: Soziologie Spezielle Grundlagen Bd 1: Situationslogik und Handeln. Campus, Frankfurt (1999)

Europäische Kommission: regions in the European union: nomenclature of territorial units for statistics; NUTS 2013/EU-28. Eurostat Theme Collection. Publ. of the Europ. Union. http://publications.europa.eu/en/publicationdetail/-/publication/a4f9243e-fa53-4798-90f4-bb51cb355a3a (2015). Accessed 15 Sept 2020

Faggian, A., McCann, P., Sheppard, S.: Human capital, higher education and graduate migration: an analysis of Scottish and Welsh students. Urban Stud. 44(13), 2511-2528 (2007). https://doi.org/10.1080/0042098070 1667177

Falk, S., Kratz, F.: Regionale Mobilität von Hochschulabsolventen beim Berufseinstieg. Beiträge Zur Hochschulforschung 31(3), 52-67 (2009)

Fuchs, M., Rauscher, C., Weyh, A.: Lohnhöhe und Lohnwachstum: Die regionalen Unterschiede in Deutschland sind groß. Nürnberg: Institut für Arbeitsmarkt-und Berufsforschung (IAB). IAB-Kurzbericht. https://www. econstor.eu/handle/10419/158438 (2014). Accessed 15 Sept 2020

Ganesch, F., Dütsch, M., Struck, O.: Regionale Mobilität am Arbeitsmarkt. Individuelle, betriebliche und wirtschaftsstrukturelle Determinanten von Mobilität und Einkommen. Köln Z Soziol 71(2), 181-210 (2019). https:// doi.org/10.1007/s11577-019-00620-y

Gerber, T.P., Cheung, S.Y.: Horizontal stratification in postsecondary education: forms, explanations, and implications. Annu. Rev. Sociol. 34, 299-318 (2008)

Glocker, D., Storck, J.: Uni, Fachhochschule oder Ausbildung: Welche Fächer bringen die höchsten Löhne? DIW-Wochenbericht 79(13), 3-8 (2012)

Grave, B.S., Goerlitz, K.: Wage differentials by field of study - the case of German university graduates. Educ. Econ. 20(3), 284-302 (2012)

Grotheer, M., Kerst, C.: Studienqualität in system-und hochschulbezogener Perspektive. Auswertungen aus Daten des Studienqualitätsmonitors und des Konstanzer Studierendensurveys. HIS: Projektbericht, Hannover (2011)

Grözinger, G.: Einflüsse auf die Notengebung: eine Analyse ausgewählter Fächer auf Basis der Prüfungsstatistik. In: Müller-Benedict, V., Grözinger, G. (eds.) Noten an Deutschlands Hochschulen, pp. 79-116. Springer, Wiesbaden (2017)

Haußen, T., Übelmesser, S.: Mobilität von Hochschulabsolventen in Deutschland. Ifo Dresden Berichtet 22(2), 42-50 (2015)

Hillmert, S.: Ausbildungssysteme und Arbeitsmarkt. Lebensverläufe in Großbritannien und Deutschland im Kohortenvergleich. Westdeutscher Verlag, Wiesbaden (2001)

Hillmert, S., Hartung, A., Weßling, K.: Dealing with space and place in standard survey data. Surv. Res. Methods 11(3), 267-287 (2017). https://doi.org/10. 18148/srm/2017.v11i3.6729

Hinz, T., Abraham, M.: Theorien des Arbeitsmarktes: Ein Überblick. In: Abraham, M., Hinz, T. (eds.) Arbeitsmarktsoziologie, pp. 17-68. Springer, Wiesbaden (2008)

Hoekstra, M.: The effect of attending the flagship state university on earnings: a discontinuity-based approach. Rev. Econ. Stat. 91(4), 717-724 (2009)

Holmlund, L.: The effect of college quality on earnings evidence from Sweden. Umeå Economic Studies 781 (2009).

Hox, J.J., Moerbeek, M., van de Schoot, R.: Multilevel Analysis: Techniques and Applications. Routledge, London (2010)

lannelli, C., Gamoran, A., Paterson, L.: Fields of study: horizontal or vertical differentiation within higher education sectors? Res. Soc. Stratif. Mobil. 57, $11-23(2018)$

Kirkeboen, L.J., Leuven, E., Mogstad, M.: Field of study, earnings, and selfselection. Q. J. Econ. 131(3), 1057-1111 (2016)

Kittelsen Røberg, K.I., Helland, H.: Do grades in higher education matter for labour market rewards? A multilevel analysis of all Norwegian graduates in the period 1990-2006. J. Educ. Work. 30(4), 383-402 (2017). https://doi org/10.1080/13639080.2016.1187265 
Klein, M.: Higher education and non-pecuniary returns in Germany: tracing the mechanisms behind field of study effects at the start of the career. Irish Educ. Stud. 30(2), 253-270 (2011). https://doi.org/10.1080/03323315. 2011.569144

Krabel, S., Flöther, C.: Here today, gone tomorrow? Regional labour mobility of German university graduates. Reg. Stud. 48(10), 1609-1627 (2014). https://doi.org/10.1080/00343404.2012.739282

Kratz, F., Brüderl, J.: Returns to regional migration: causal effect or selection on wage growth? Schmollers Jahr. 133(2), 227-238 (2013). https://doi.org/ 10.3790/schm.133.2.227

Leuze, K., Strauß, S.: Lohnungleichheiten zwischen Akademikerinnen und Akademikern: Der Einfluss von fachlicher Spezialisierung, frauendominierten Fächern und beruflicher Segregation. Z Soziol 38(4), 262-281 (2009)

Lucas, S.R.: Effectively maintained inequality: education transitions, track mobility, and social background effects. Am. J. Sociol. 106(6), 1642-1690 (2001)

Madelin, M., Grasland, C., Mathian, H., Sanders, L., Vincent, J.-M.: Das "MAUP": modifiable areal unit_-problem oder Fortschritt? Informationen Zur Raumentwicklung. 10, 645-660 (2009)

Marchenko, Y.V.: Estimating variance components in Stata. Stata J. 6(1), 1-21 (2006). https://doi.org/10.1177/1536867X0600600101

Maretzke, S.: Regionales Einkommen in Abhängigkeit von regionalen Strukturunterschieden. Informationen zur Raumentwicklung (1), 67-84 (2013).

Monks, J.: The returns to individual and college characteristics: evidence from the National Longitudinal Survey of Youth. Econ. Educ. Rev. 19(3), 279-289 (2000)

Noelke, C., Gebel, M., Kogan, I.: Uniform inequalities: institutional differentiation and the transition from higher education to work in post-socialist Central and Eastern Europe. Eur. Sociol. Rev. 28(6), 704-716 (2012). https://doi. org/10.1093/esr/jcs008

Peer, V., Penker, M.: Higher education institutions and regional development. Int. Regional Sci. Rev. 39(2), 228-253 (2016). https://doi.org/10.1177/ 0160017614531145

Rabe-Hesketh, S., Skrondal, A.: Multilevel and Longitudinal Modeling Using Stata. Stata Press Publication, College Station (2012)
Ragnitz, J.: Regionale Lohnunterschiede in Deutschland. Ifo Dresden Berichtet 19(2), 26-32 (2012)

Rehn, T., Brandt, G., Fabian, G., Briedis, K.: Hochschulabschlüsse im Umbruch. Studium und Übergang von Absolventinnen und Absolventen reformierter und traditioneller Studiengänge des Jahrgangs 2009. Forum Hochschule, HIS (2011)

Reimer, D., Noelke, C., Kucel, A.: Labor market effects of field of study in comparative perspective: an analysis of 22 European countries. Int. J. Comp. Sociol. 49(4-5), 233-256 (2008)

Spence, M.: Job market signaling. Q. J. Econ. 87(3), 355-374 (1973)

Statistisches Bundesamt: Fächersystematik: Systematik der Studienfächer, Studiebereiche und Fächergruppen (Wintersemester 2008/2009) des Statistischen Bundesamtes (Destatis). Fachserie 11, Reihe 4.1, WS 2008/2009 (n.d.)

Suhonen, T.: Are there returns from university location in a state-funded university system? Reg. Sci. Urban Econ. 43(3), 465-478 (2013)

Triventi, M.: The role of higher education stratification in the reproduction of social inequality in the labor market. Res. Soc. Stratif. Mobil. 32, 45-63 (2013)

van de Werfhorst, H., Kraaykamp, G.: Four field-related educational resources and their impact on labor, consumption, and sociopolitical orientation. Sociol. Educ. 74(4), 296-317 (2001)

Wissenschaftsrat: Empfehlungen zur Differenzierung der Hochschulen. Drs. 10387-10, Lübeck (2010)

\section{Publisher's Note}

Springer Nature remains neutral with regard to jurisdictional claims in published maps and institutional affiliations.

\section{Submit your manuscript to a SpringerOpen ${ }^{\circ}$ journal and benefit from:}

- Convenient online submission

- Rigorous peer review

- Open access: articles freely available online

- High visibility within the field

- Retaining the copyright to your article

Submit your next manuscript at springeropen.com 